19 Revue d'histoire du XIXe siècle

Société d'histoire de la révolution de 1848 et des

révolutions du XIXe siècle

48 | 2014

Usages du droit

\title{
Deuil. Maurice Agulhon (1926-2014)
}

\section{Sylvie Aprile}

\section{OpenEdition \\ Journals}

Édition électronique

URL : http://journals.openedition.org/rh19/4650

DOI : $10.4000 /$ rh 19.4650

ISSN : $1777-5329$

Éditeur

La Société de 1848

Édition imprimée

Date de publication : 1 juin 2014

Pagination : 7

ISSN : 1265-1354

\section{Référence électronique}

Sylvie Aprile, "Deuil. Maurice Agulhon (1926-2014) », Revue d'histoire du XIXe siècle [En ligne], 48 |

2014, mis en ligne le 16 septembre 2014, consulté le 22 septembre 2020. URL : http://

journals.openedition.org/rh19/4650; DOI : https://doi.org/10.4000/rh19.4650 


\section{DEUIL}

\section{Maurice Agulhon (1926-2014)}

Il est des premières fois que l'on souhaite, d'autres que l'on redoute. Je n'avais, pour l'instant, jamais eu à reprendre la tradition du "mot du président" pour annoncer la mort de l'un de nos anciens présidents. Certes, nous savions que l'état de santé de Maurice Agulhon s'était considérablement dégradé ces derniers mois, mais nous n'en sommes pas moins, aujourd'hui, frappés dans un compagnonnage ou une filiation. Nous avons tous lu et relu la République au Village, nous l'avons prêtée, rachetée, annotée. Il faudrait également évoquer Pénitents et francs-maçons de l'ancienne Provence, qui a joué un rôle intellectuel considérable, son « $\mathrm{Vu}$ des coulisses» dans les Essais d'ego-histoire et ses travaux sur Marianne. Dans ces quelques lignes, je ne retracerai ni la carrière, ni l'œuvre, ni le rôle majeur de Maurice Agulhon dans la résurrection de notre Société, à laquelle la RH19 est étroitement liée. Nous lui consacrerons un dossier plus ample dans un prochain numéro. Nous tenions ici seulement, avec ceux qui l'ont bien connu et à la veille du bouclage du dernier numéro de la revue qui lui était chère, à partager avec vous tous souvenirs et émotions.

Sylvie Aprile, présidente de la Société d'histoire de la Révolution de 1848 et des révolutions du XIXe siècle

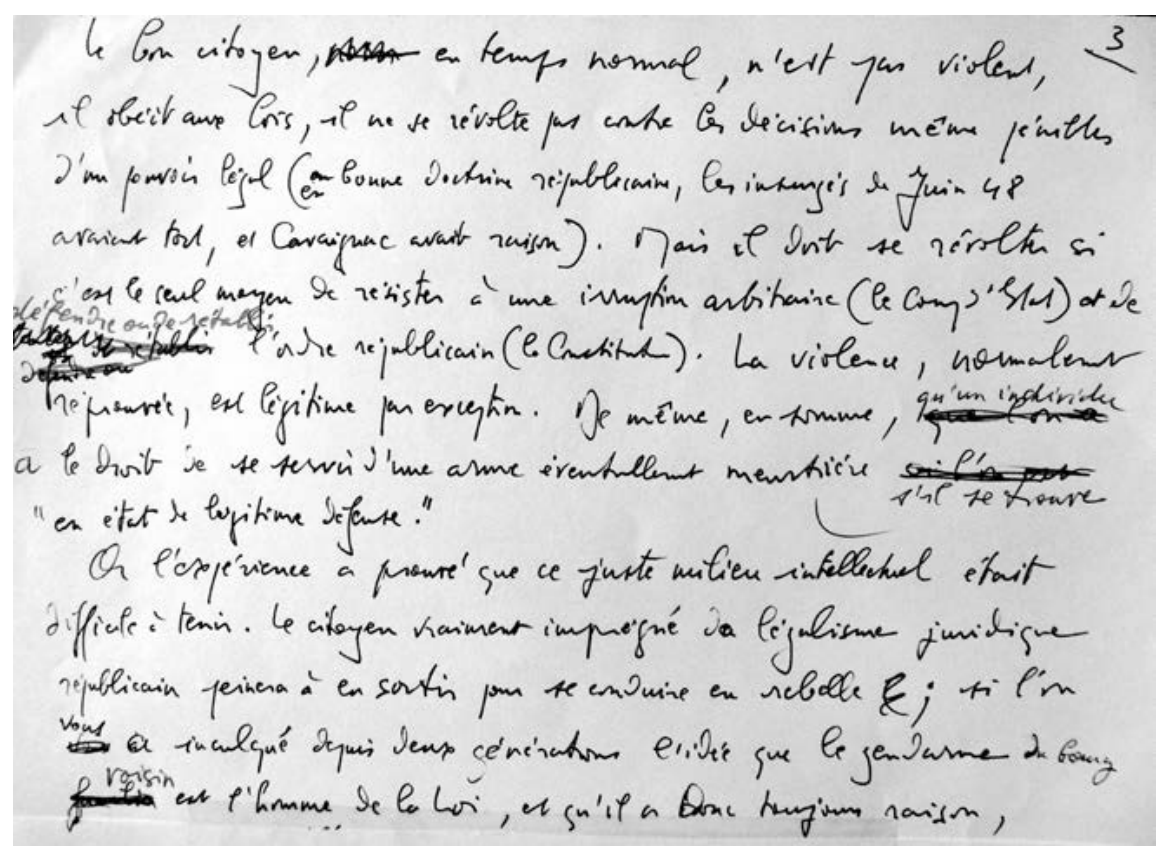

Manuscrit de l'article de Maurice Agulhon publié dans notre revue en 2001, «Mémoire et tourisme. Les monuments provençaux de 1851» 